Marquette University

e-Publications@Marquette

Biological Sciences Faculty Research and

Publications

Biological Sciences, Department of

$9-5-2009$

\title{
Tropical Dry Forest Succession and the Contribution of Lianas to Wood Area Index (WAI)
}

\author{
Arturo Sanchez-Azofeifa \\ University of Alberta -Edmunton \\ Margaret Kalacska \\ University of Alberta -Edmunton \\ Mario Marcos do Espirito-Santo \\ Universidade Estadual de Montes Claros \\ G. Wilson Fernandes \\ Universidade Federal de Minas Gerais, \\ Stefan A. Schnitzer \\ Marquette University, stefan.schnitzer@marquette.edu
}

Follow this and additional works at: https://epublications.marquette.edu/bio_fac

Part of the Biology Commons

\section{Recommended Citation}

Sanchez-Azofeifa, Arturo; Kalacska, Margaret; do Espirito-Santo, Mario Marcos; Fernandes, G. Wilson; and Schnitzer, Stefan A., "Tropical Dry Forest Succession and the Contribution of Lianas to Wood Area Index (WAI)" (2009). Biological Sciences Faculty Research and Publications. 673.

https://epublications.marquette.edu/bio_fac/673 
Marquette University

e-Publications@Marquette

\section{Biology Faculty Research and Publications/College of Arts and Sciences}

This paper is NOT THE PUBLISHED VERSION; but the author's final, peer-reviewed manuscript. The published version may be accessed by following the link in th citation below.

Forest Ecology and Managment, Vol. 258, No. 6 (September 5, 2009): 941-948. DOI. This article is (C) Elsevier and permission has been granted for this version to appear in e-Publications@Marquette. Elsevier does not grant permission for this article to be further copied/distributed or hosted elsewhere without the express permission from Elsevier.

\section{Tropical dry forest succession and the contribution of lianas to wood area index (WAI)}

\section{G. Arturo Sánchez-Azofeifa}

Earth Observation Systems Laboratory, Earth and Atmospheric Sciences Department, University of Alberta, Edmonton, Alberta, Canada

Smithsonian Tropical Research Institute (STRI), Box 2072, Balboa, Ancon, Panama

Margaret Kalácska

Earth Observation Systems Laboratory, Earth and Atmospheric Sciences Department, University of Alberta, Edmonton, Alberta, Canada T6G 2E3

Mario Marcos do Espírito-Santo

Departmento de Biologia Geral/CCBS, Universidade Estadual de Montes Claros, Montes Claros, Minas Gerais, Brazil

G. Wilson Fernandes

Ecologia Evolutiva \& Biodiversidade/DBG, ICB/Universidade Federal de Minas Gerais, CP 486, 30161 970 Belo Horizonte MG, Brazil

Stefan Schnitzer

Department of Biological Sciences, University of Wisconsin-Milwaukee, PO Box 413, Milwaukee, WI 53201, USA 
Earth Observation Systems Laboratory, Earth and Atmospheric Sciences Department, University of Alberta, Edmonton, Alberta, Canada T6G 2E3

\begin{abstract}
The transmission and interception of light through the canopy is an important indicator of forest productivity in tropical forest ecosystems, and the amount of light that eventually reaches the forest floor is influenced by its interactions with leaves, branches, fruits, and flowers among many different canopy elements. While most studies of forest canopy light interception focus on leaf area index (LAI), very few studies have examined wood area index (WAI), which may account for a substantial component of light interception in tropical forests. The influence of lianas on the interception of light and their overall contribution to WAI is a potentially important factor, but it is generally overlooked because of its difficulty to assess. In this paper we evaluate the relative contribution that lianas have to the overall WAI and canopy openness as function of successional stage via a latitudinal comparison of sites across the Americas (Mexico, Costa Rica and Brazil). Our results suggest that lianas significantly increase WAI and decreases canopy openness. However, lianas were absent at all of our study sites where canopy openness exceeded $60 \%$. Our data are the first to explicitly document the role of lianas in the estimation of WAI and, overall, they will contribute to better estimations of ecosystem level LAl in tropical environments, where there is a lack of data on WAI.
\end{abstract}

\title{
Keywords
}

Canopy ecology, Leaf area index, Light, Tropical ecology, Succession

\section{Introduction}

The transmission of incoming light through the tropical forest canopy, and eventually the amount of light that reaches the ground is influenced by a complex interaction between branches, flowers, other non-photosynthetic components as well as the angle and distribution of the leaves across a vertical profile (Kucharik et al., 1998, Montgomery and Chazdon, 2001, Palomaki et al., 2006). Leaf area index (LAI) in tropical environments is used as an indirect measurement of such complexity. LAl is defined as one-half of the total leaf area per unit ground surface area (Leblanc and Chen, 2001, Morisette et al., 2006). From a biophysical point of view, LAl plays an important role in our understanding of primary production, water balance, carbon absorption and gas exchange of the canopy with the atmosphere (Clark et al., 2008). From an ecological point of view, LAI serves as a proxy for characterizing a tropical ecosystem's successional stage (i.e., differentiation between early, intermediate and late succession) (Oberbauer et al., 1993, Bonan et al., 2002, Kalácska et al., 2004, Kalácska et al., 2005a, Kalácska et al., 2005b, Hoffmann et al., 2005).

Measuring LAI in tropical environments is a complex and difficult task (Clark et al., 2008). LAl measurements are in general obtained via the use of optical techniques such as digital hemispherical cameras and instruments such as the LICOR-2000 Plant Canopy Analyzer (Welles, 1990, Welles and Cohen, 1996, Fournier et al., 2003). Actual LAl is derived from factoring total plant area index $\left(L_{t}\right)$ by the amount of total woody material (wood area index (WAI)) that forms part of the canopy architecture (Chen et al., 1997). Based on Leblanc and Chen (2001) LAI is defined as:

$$
\mathrm{LAI}=L t(1-\mathrm{WAI})=\frac{L_{e}(1-\mathrm{WAI})}{\Omega}
$$

where WAl is the wood area index representing the woody material contribution to the total plant area index $\left(L_{t}\right)$ while $\Omega$ is defined as the clumping factor. $\Omega$ is particularly significant for canopies that show non-random branch elements such as conifers. It can be estimated via destructive sampling or gap fraction analysis, both of 
which exceed the scope of most studies in tropical environments (but see Clark et al., 2008). Thus, due to practical reasons $\Omega$ is considered to be equal to 1 in many tropical environments.

The relative contributions of plant area index $\left(L_{t}\right)$, WAI and LAI across different types of tropical ecosystems is poorly understood. LAl varies across the succession stages in many tropical moist and rainforest environments (Saldarriaga and Luxmoore, 1991, Szott et al., 1994, Ferment et al., 2001, Duarte et al., 2002, Lucas et al., 2002, Kalácska et al., 2004, Liao et al., 2006). Leaf area index data for tropical dry forests (Maass et al., 1995, Kalácska et al., 2005a, Kalácska et al., 2005b) or tropical savannas (such as the Brazilian Cerrado) is more limited (Hoffmann et al., 2005). There is a particular dearth of information on WAl due to the difficulties in its quantification. In general, accurate estimations of WAI are expensive and time consuming, and destructive sampling is often the only option available for the quantification of WAl in tropical evergreen forests (Clark et al., 2008).

Work on the quantification of WAI in tropical dry forests has been conducted indirectly by Maass et al. (1995) at the Chamela Biological Station in Mexico, and Kalácska et al., 2005a, Kalácska et al., 2005b at the Santa Rosa and Palo Verde National Parks in Costa Rica and the Chamela Biological Station in Mexico. However, for both studies, the contribution of lianas to WAI was not documented. Maass et al. (1995) quantified total WAI without making a differentiation between the presence or absence of liana communities, while Kalácska et al. (2005a) indicated the relative contribution of liana leaves to the LAI but did not quantify the contribution of this structural group to the total $L_{t}$.

Lianas are climbing plants that suppress the growth and fecundity, as well as increase the mortality rates of their host trees (Putz, 1983, Hegarty and Caballé, 1992, Laurance et al., 2001, Pérez-Salicrup, 2001, Pérez-Salicrup et al., 2001, Schnitzer and Bongers, 2002, Pérez-Salicrup and de Meijere, 2005). Furthermore, lianas tend to form mat-like layers on top of the canopy, with branches entangled in the forest canopy (Kalácska et al., 2007), reducing the amount of light that reaches the ground. This life form represents $<10 \%$ of the total tropical biomass and is usually ignored in many forest inventories, though lianas can account for up to $40 \%$ of leaf productivity (Hegarty and Caballé, 1992, Phillips et al., 2002). The significance of lianas as a fingerprint of climate change in tropical environments has been highlighted by Phillips et al. (2002), Wright et al. (2004), and Mohan et al. (2006), since lianas appear to respond positively to global climate change.

Tropical dry forests, due to their marked seasonality, present a unique opportunity to document changes in WAI as a function of successional stage and density of liana coverage given the higher occurrence of lianas when compared with other tropical ecosystems (Schnitzer, 2005). Therefore, in the context of the limited information available from Kalácska et al., 2005a, Kalácska et al., 2005b, this paper examines, for the first time, changes in WAI and canopy openness between liana infested and non-liana infested sites across a latitudinal cross-section from Mexico to Brazil at two levels: liana vs. no liana presence and as a function of successional stage.

\section{Materials and methods}

\subsection{Study sites}

We conducted our work in four sites with different successions of tropical dry forests located in Mexico, Costa Rica and Brazil spanning a climatic gradient of very dry forest (Chamela-Cuixmala, Mexico; $752 \mathrm{~mm}$ average yearly precipitation, 383-1393 mm yearly precipitation range) to transitional dry forest (Santa Rosa, Costa Rica; $1500 \mathrm{~mm}$ average yearly precipitation, $915-2258 \mathrm{~mm}$ yearly precipitation range). Tropical dry forest successions were defined following Kalácska et al. (2005a).

The most northerly site, and also the driest, is located in the Chamela-Cuixmala Biosphere reserve (3300 ha) on the west coast of Mexico $\left(19^{\circ} 22^{\prime} \mathrm{N}-19^{\circ} 39^{\prime} \mathrm{N}, 104^{\circ} 56^{\prime} \mathrm{W}-105^{\circ} 0^{\prime} \mathrm{W}\right)$ (heretofore named $\mathrm{CH}$ ). High endemism and 
species richness are characteristic of this site (Lott, 1985), and forest types span from early secondary growth to largely undisturbed forest (Maass and Martinez-Yrizar, 2001, Kalácska et al., 2005b). In this study, we refer to four physiognomically different forest types based on successional stage (Arroyo-Mora et al., 2005). The early successional stage (E) in Chamela-Cuixmala is populated entirely by Acacia sp. bushes with a DBH below $5 \mathrm{~cm}$. The intermediate successional stage $(\mathrm{I})$ is a secondary forest comprising a canopy with several gaps, a thick herbaceous understory and several vines and liana species. For the mature forest, we refer to two sub-types: upper ridge-top and Riparian. The upper ridge-top forest is largely undisturbed with a very high tree and liana stem densities and presence of lianas (U) (Table 1). The Riparian forest (R) is also considered to be relatively undisturbed and many of the trees and lianas are evergreen throughout the dry season (Rzedowski, 1978) (Table 1). In general, the forest in Chamela-Cuixmala is dry season deciduous, although differences in phenology exist between the deciduous and Riparian vegetation (Lott et al., 1987, Balvanera et al., 2002).

Table 1. Summary of canopy structure and number of sites ( 0.1 ha) at each geographical location. $\mathrm{CH}=\mathrm{Chamela-}$ Cuixmala Biosphere Reserve - Mexico, SR = Santa Rosa National Park - Costa Rica, PV = Palo Verde National Park - Costa Rica, MS = Mata Seca State Park - Brazil. Regarding successional stages, E = early, I = intermediate, $\mathrm{L}=$ late, $\mathrm{U}=$ upper ridge-top, $\mathrm{R}=$ riparian. Values represent the mean \pm one standard deviation. Data represents woody vegetation with stems with a $\mathrm{DBH} \geq 5 \mathrm{~cm}$.

\begin{tabular}{|c|c|c|c|c|c|c|}
\hline $\begin{array}{l}\text { Location - } \\
\text { stage }\end{array}$ & $\begin{array}{l}\text { Canopy } \\
\text { height }(m)\end{array}$ & $\begin{array}{l}\text { No. of } \\
\text { stems }\end{array}$ & $\begin{array}{l}\text { No. of } \\
\text { species }\end{array}$ & $\begin{array}{l}\text { Basal area } \\
\left(\mathrm{m}^{2} / \mathrm{ha}\right)\end{array}$ & $\begin{array}{l}\text { No. of sites } \\
\text { CO and WAI }\end{array}$ & $\begin{array}{l}\text { No. of sites structure } \\
\text { - composition }\end{array}$ \\
\hline $\mathrm{CH}-\mathrm{MX}-\mathrm{E}$ & $\mathrm{N} / \mathrm{A}$ & N/A & N/A & $\mathrm{N} / \mathrm{A}$ & 2 & 2 \\
\hline$S R-C R-E$ & $7.5 \pm 2.2$ & $112 \pm 64$ & $17 \pm 7$ & $11.7 \pm 5.4$ & 7 & 10 \\
\hline$P V-C R-E$ & $7.2 \pm 0.8$ & $79 \pm 25$ & $7 \pm 4$ & $28.2 \pm 18.5$ & 6 & 6 \\
\hline$M S-B R-E$ & 3.4 & 49 & 10 & 3.1 & 6 & 6 \\
\hline $\mathrm{CH}-\mathrm{MX}-\mathrm{I}$ & $11.0 \pm 2.4$ & $146 \pm 104$ & $8 \pm 6$ & $35.7 \pm 11.8$ & 4 & 4 \\
\hline SR-CR - I & $10.3 \pm 3.4$ & $130 \pm 35$ & $29 \pm 5$ & $21.4 \pm 6.8$ & 6 & 10 \\
\hline PV-CR - I & $15.0 \pm 2.2$ & $78 \pm 28$ & $14 \pm 3$ & $35.7 \pm 11.8$ & 6 & 6 \\
\hline MS-BR - I & 8.0 & 76 & 17 & 15.2 & 6 & 6 \\
\hline $\begin{array}{l}\text { CH-MX - L } \\
\text { (U) }\end{array}$ & $9.0 \pm 2.2$ & $181 \pm 5$ & $31 \pm 12$ & $13.2 \pm 2.5$ & 4 & 4 \\
\hline $\begin{array}{l}\text { CH-MX - L } \\
\text { (R) }\end{array}$ & $20.0 \pm 2.0$ & $124 \pm 10$ & $32 \pm 5$ & $32.9 \pm 3.2$ & 3 & 3 \\
\hline$S R-C R-L$ & $15.0 \pm 2.2$ & $107 \pm 42$ & $29 \pm 7$ & $30.1 \pm 6.5$ & 3 & 6 \\
\hline PV-CR - L & $18.3 \pm 1.5$ & $64 \pm 12$ & $19 \pm 7$ & $29.2 \pm 8.1$ & 3 & 3 \\
\hline \multirow[t]{2}{*}{ MS-BR - L } & 11.8 & 99 & 18 & 22.0 & 8 & 8 \\
\hline & & & & Total & 64 (6.4 ha) & 74 (7.4 ha) \\
\hline
\end{tabular}

The second study site, and the one which receives the most precipitation, is the Santa Rosa National Park in the Área de Conservacion Guanacaste, located in northwestern Costa Rica $\left(10^{\circ} 48^{\prime} \mathrm{N}, 85^{\circ} 36^{\prime} \mathrm{W}\right)$ (heretofore named SR). This area is considered transitional between a dry and moist forest. The uplands of the park are a mosaic of secondary forest in various stages of succession and with different land use histories and anthropogenic fires (Janzen, 1988a, Janzen, 1988b, Janzen, 1988c, Janzen, 2000, Kalácska et al., 2004, Arroyo-Mora et al., 2005). We refer to three stages of succession in this study site: early, which constitutes a forest with a very open and patchy canopy and a thick herbaceous understory; intermediate, a forest with a range of canopy openness and high abundance of lianas; and late, which constitutes a canopy with two layers of vegetation: dominant canopy trees and shade tolerant species (Table 1 ). 
The third study site is located in the Palo Verde National Park, Costa Rica $\left(10^{\circ} 21^{\prime} \mathrm{N}, 85^{\circ} 21^{\prime} \mathrm{W}\right)$ in the Área de Conservacion Tempisque, along the Tempisque River, in the NW part of the country (heretofore named PV). Deciduous forest is present in seasonally flooded lowlands and along limestone outcrops. Savannah, mesic forest, mangroves and a fresh water wetland are also present (Frankie et al., 1974). The average yearly precipitation is $1353 \mathrm{~mm}$ with a range from 713 to $2130 \mathrm{~mm}$. Cattle ranching was a common land use in the area from the 1920s until the 1970s when 4800 ha were declared a wildlife refuge (Stern et al., 2002). Officially, Palo Verde National Park (10,000 ha) was created in 1981. As with the two previously described sites, we refer to different stages of forest succession. The early stage has a very thick seasonal herbaceous understory and a largely open canopy with sparse trees, all of which are deciduous (Table 1). The intermediate stage presents a heterogeneous canopy with areas comprising up to two layers of vegetation, a variable density of lianas, and a thick understory. In both the early and intermediate stages there is a high abundance of bromeliads, and in the intermediate stage there are many short-stature palms. The late stage is characterized by two layers of vegetation (dominant canopy vegetation and shade tolerant trees) with a relatively high presence of lianas and few canopy gaps (Kalácska et al., 2005b; $\underline{\text { Table 1)}) . ~}$

The most southerly site, Parque Estadual da Mata Seca (10,281 ha), is located in the State of Minas Gerais, Brazil, in the valley of the São Francisco River $\left(14^{\circ} 48^{\prime} 36^{\prime \prime} \mathrm{S}-14^{\circ} 56^{\prime} 59^{\prime \prime} \mathrm{S}\right.$ and $43^{\circ} 55^{\prime} 12^{\prime \prime} \mathrm{W}-44^{\circ} 04^{\prime} 12^{\prime \prime} \mathrm{W}$ ) (heretofore named MS). The forest is dry season deciduous (May-October) (Instituto Estadual de Florestas, 2000) and receives an average of $871 \mathrm{~mm}$ of precipitation per year (Antunes, 1994). The park, classified as a conservation unit of integral protection, was created in 2000 by the expropriation of four farms and is currently managed by the Minas Gerais' Instituto Estadual de Florestas (Instituto Estadual de Florestas, 2000). A portion (1525 ha) of the park consists of abandoned pasture and agricultural fields in various stages of natural regeneration, while the remainder of the area is secondary and old growth forest (Instituto Estadual de Florestas, 2000). As for the previously described sites, we refer to three stages of forest succession in Parque Estadual da Mata Seca: early, intermediate and late (Table 1). The early stage is composed of a heterogeneous canopy with a herbaceous and shrubby understory, and no lianas have been recorded so far. The intermediate stage comprises up to two layers in some areas with canopy gaps in others. Lianas are predominant in this stage. The late stage represents mature forest with increased number of stems, species and a higher basal area than the other stages (Table 1).

\subsection{Field sampling, canopy openness and wood area index}

In all sites, living woody stems with a DBH equal to or greater than $5 \mathrm{~cm}$ were identified in plots of $20 \mathrm{~m} \times 50 \mathrm{~m}$ (0.1 ha) (Table 1). In addition, the height of the six tallest trees was recorded in each plot. During the dry season, ten hemispherical photographs were taken inside each plot using a Pentax SR digital camera with a standard hemispherical lens (polar projection) to assess canopy openness and WAl. The photographs were taken based on an offset row sampling scheme (Kalácska et al., 2005a) and were subsequently processed with Gap Light Analyzer v.2.0 (SFU-IES, 1999). The polar projection of the sphere was projected in the plot prior to any measurement to avoid overlaps and thus autocorrelation between the data observed via hemispherical lens. The presence or absence of lianas was assessed visually from each photograph and from field observations (Chamela-Cuixmala: 46 lianas and 96 no-lianas photos in March 2006; Santa Rosa: 72 lianas and 39 no-lianas photos in March 2005; Palo Verde: 21 lianas and 84 no-lianas photos in March 2006; and Mata Seca: 66 lianas and 60 no-lianas photos in July 2006).

\subsection{Analyses}

In each sampled location (each region), differences in mean canopy openness (CO) and WAI between sample points with and without lianas were assessed by means of an ANOVA for Santa Rosa, where the data met assumptions of normality and a non-parametric Kruskal-Wallis was used for the others (Zar, 1996). Overall differences in mean $\mathrm{CO}$ or WAI between plots with and without lianas regardless of location were also assessed in the same manner and using probability density functions. Within each location (i.e., CH, SR, PV, MS) we 
examined differences in mean canopy openness and WAI for across the three successional stages in each site, by means a $t$-test (with unequal variance) when the $\mathrm{CO}$ or WAI met the assumption of normality, while the Wilcoxon rank sum test was used for the others. At all sites ( $\mathrm{CH}, \mathrm{SR}, \mathrm{PV}$, and $\mathrm{MS}$ ), there were only two successional stages in the comparison (intermediate and late for $\mathrm{CH}, \mathrm{PV}, \mathrm{MS}$ ) because there were no lianas observed in the early stage. For SR, no lianas were observed in the late stage; therefore the comparison was only with the early and intermediate stages. Significance was assessed at the $P<0.05$ level. The relationship between WAI and CO was examined by means of least squares linear regression. All statistical analyses were performed with $\mathrm{JMP}^{\bullet}$ v. 5.1 (Statistical Discovery from SAS).

\section{Results}

\subsection{Overall latitudinal changes}

Results from the latitudinal cross-sequence of tropical dry forests in the Americas (Table 1) indicate that in general, sites with lianas have a higher WAI than sites without lianas. Wood area index ranged from 0.19 (MS) to $1.82(\mathrm{PV})$ in sites with lianas and 0.0 (MS) to $1.82(\mathrm{PV})$ in sites without lianas. The average for WAl across all sites with lianas is $0.70 \pm 0.31$ S.D., in comparison to sites without lianas at $0.51 \pm 0.34$ S.D. $\chi^{2}=55.10, P<0.001$, Fig. 1). In both cases the probability density function for sites with lianas and without lianas are different (Fig. 1). These results presented in Fig. 1 support the hypothesis that sites with lianas will present higher WAI values.

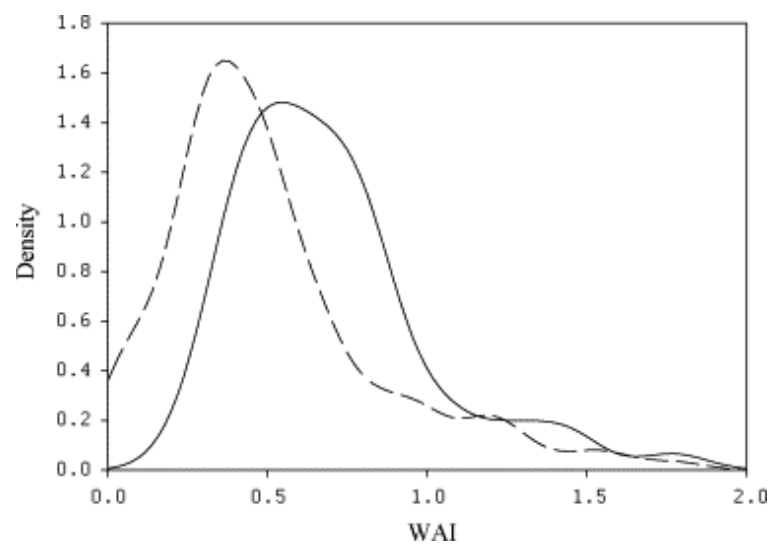

Fig. 1. Standard probability functions for wood area index for sites with and without liana coverage. Probability density functions are for data from all sites measured in Mexico, Costa Rica and Brazil. Solid lines represent liana infested plots and dash lines represent non-liana infested plots.

Canopy openness was found to be a strong predictor of WAI in all locations (Fig. 2), with different relationships existing for sites with and without lianas. The average canopy openness across (CO) all sites with lianas was $46.9 \% \pm 10.5 \%$ in comparison to $57.6 \% \pm 15.9 \%$ in sites without lianas $\left(X^{2}=62.53, P<0.001\right)$. Canopy openness ranged from $20.1 \%(P V)$ to $73.6 \%(C H)$ in sites with lianas in comparison to $20.0 \%$ (PV) to $98.0 \%(P V)$ in sites without lianas. Lianas were not observed above a canopy openness of $60-75 \%$ in any of the sites studied. 


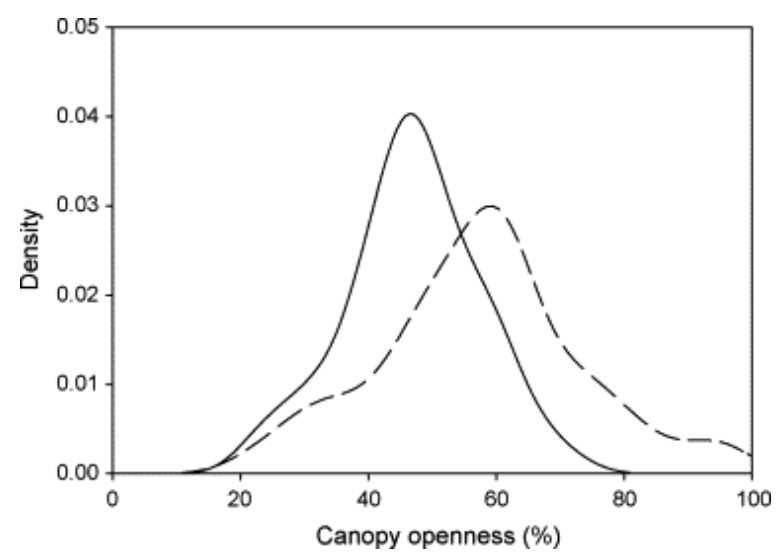

Fig. 2. Standard probability functions for canopy openness for sites with and without liana coverage. Probability density functions are for data from all sites measured in Mexico, Costa Rica and Brazil. Solid lines represent liana infested plots and dash lines represent non-liana infested plots.

\subsection{Regional differences}

For Chamela-Cuixmala, when all data are considered (Figs. $\underline{3} a, \underline{4} a$ and $\underline{5}$ ), sites with lianas have a significantly higher WAI $\left(\chi^{2}=18.52, P<0.001\right)$ and less canopy openness (CO) $\left(\chi^{2}=20.67, P<0.001\right)$. At the successional stage level, the same trend is seen in the late (CO: $Z=-3.43, P<0.001$, WAI: $Z=3.34, P<0.001)$ stage, but not in the intermediate (CO: $Z=1.44, P=0.15$, WAI: $Z=1.27, P=0.21$ ). Lianas were not present in the early stage.
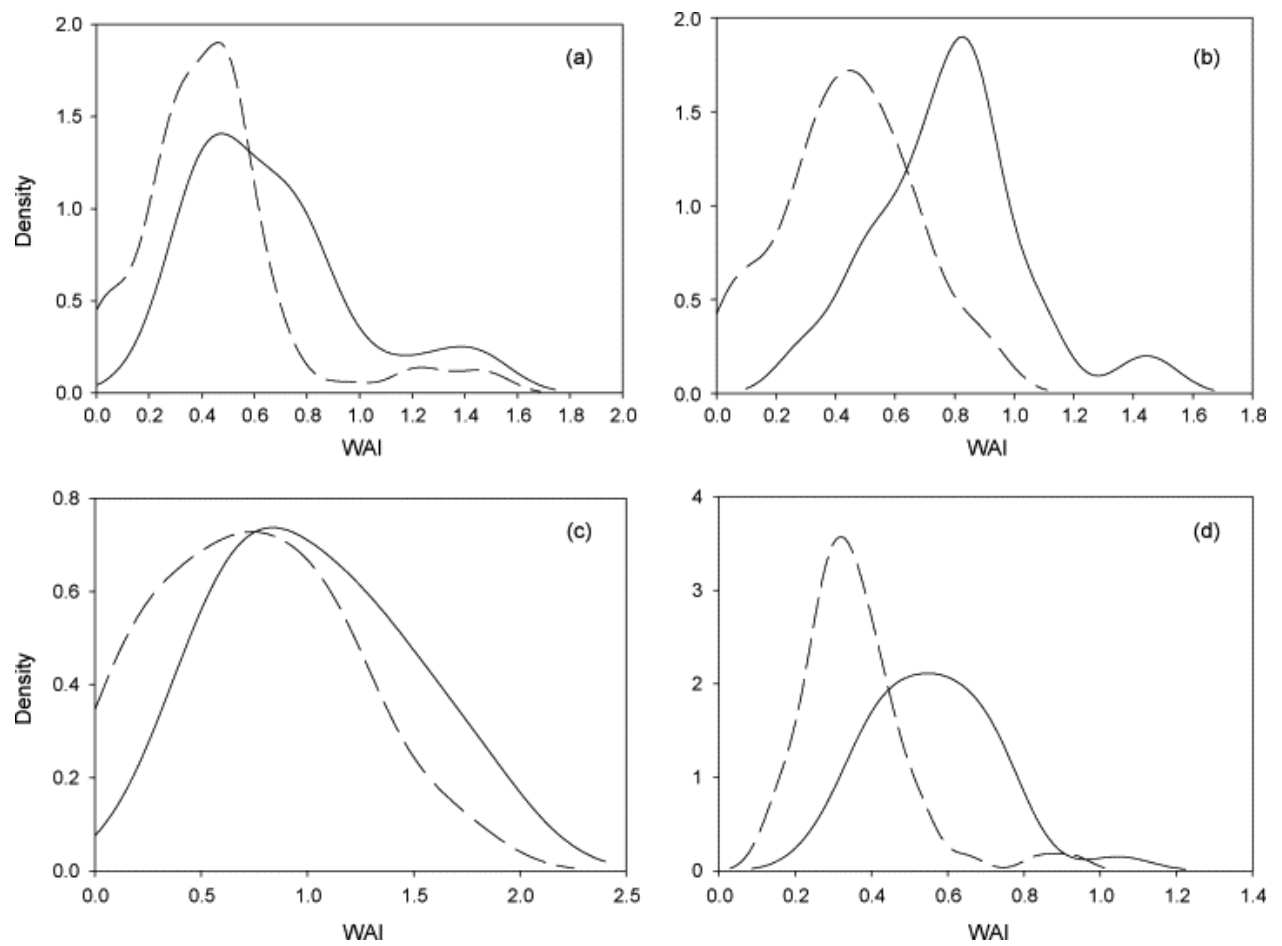

Fig. 3. Standard probability functions for wood area index at each simple site. Chamela-Cuixmala Biosphere Reserve, Mexico (a); Santa Rosa National Park, Costa Rica (b); Palo Verde National Park, Costa Rica (c); and Parque Stadual de Mata Seca, Minas Gerais, Brazil (d). Solid lines represent liana infested plots and dash lines represent non-liana infested plots. 

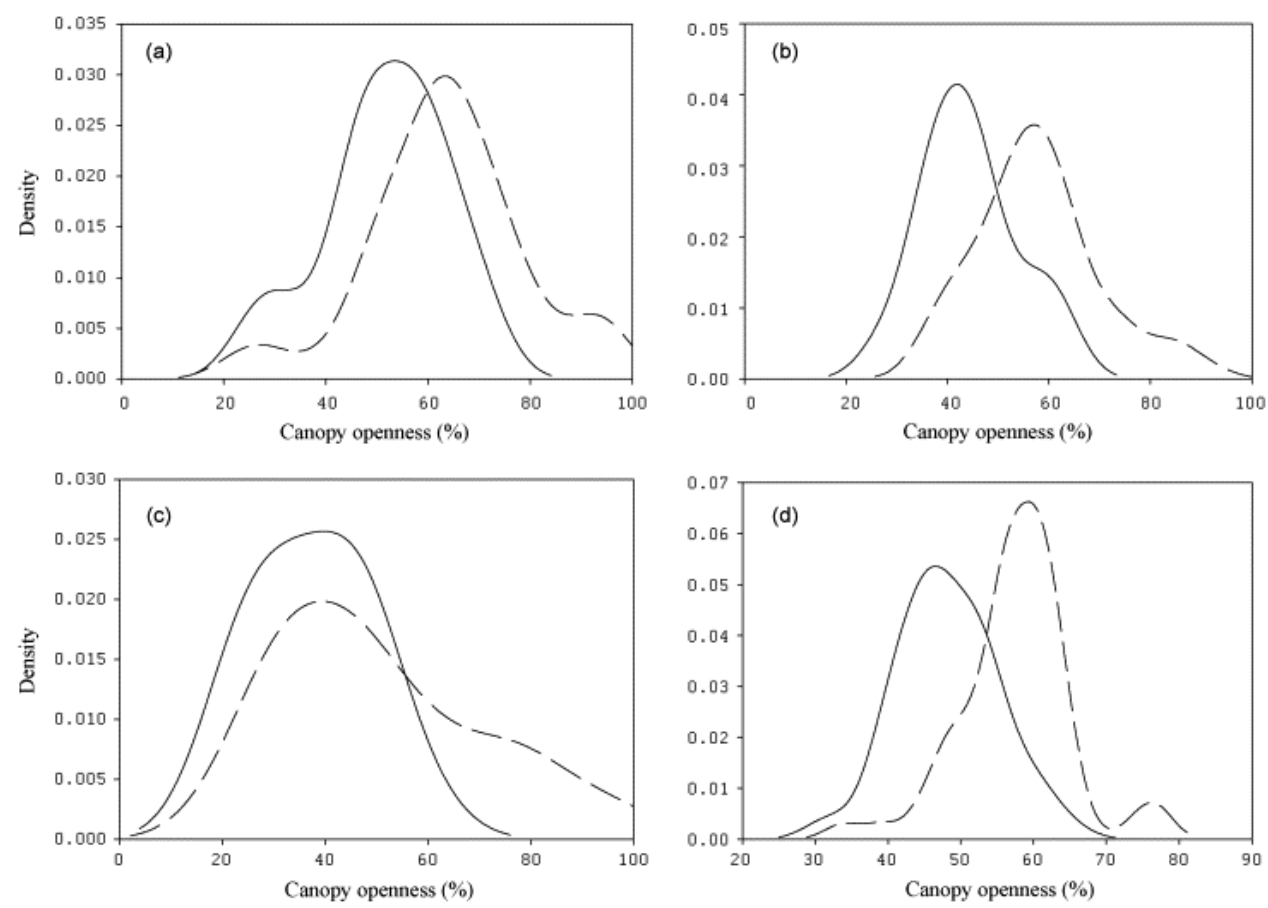

Fig. 4. Standard probability functions for Canopy openness sites with and without liana coverage. Probability density functions are for all sites measured in Mexico, Costa Rica and Brazil. Solid lines represent liana infested plots and dash lines represent non-liana infested plots.

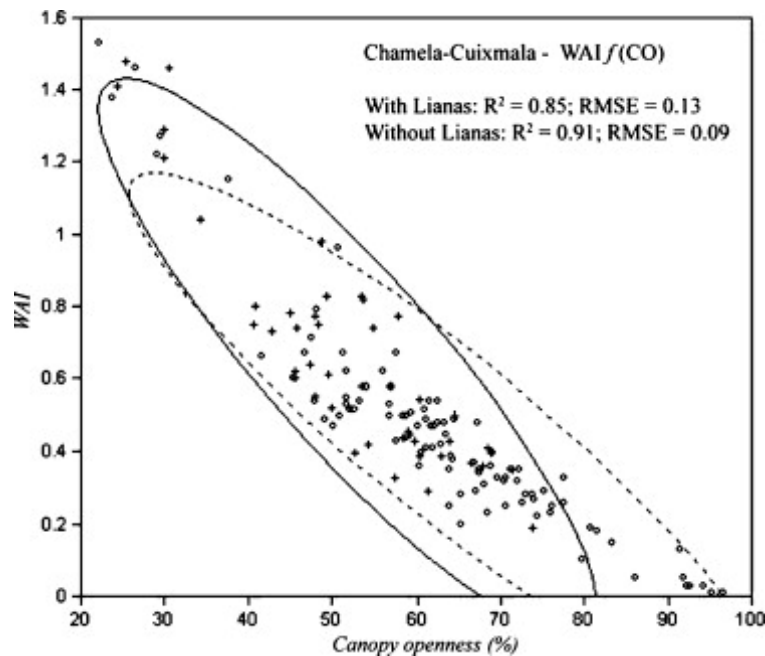

Fig. 5. Relationship between canopy openness (\%) and WAI for Chamela-Cuixmala, Mexico (b). Open circles and solid line represent data points with lianas, + and dotted line represent data points without lianas. Ellipses represent 95\%. Inset: Mean and one standard deviation for canopy openness (\%) and WAI.

For Santa Rosa, when all data are considered (Figs. $\underline{3} b, \underline{4} b$ and $\underline{6}$ ), similar to Chamela-Cuixmala, sites with lianas have a significantly higher WAI $(F=52.59, P<0.001)$ and less canopy openness $(F=36.21, P<0.001)$. At the succession stage level, the same trend was seen for both the early (CO: $Z=-3.65, P=0.03$;

WAl: $Z=3.76, P<0.001$ ) and intermediate succession stages (CO: $Z=2.27, P=0.02$ WAl: $Z=-2.79, P=0.01$ ). Lianas were not present in the photographs from the late succession stage. 


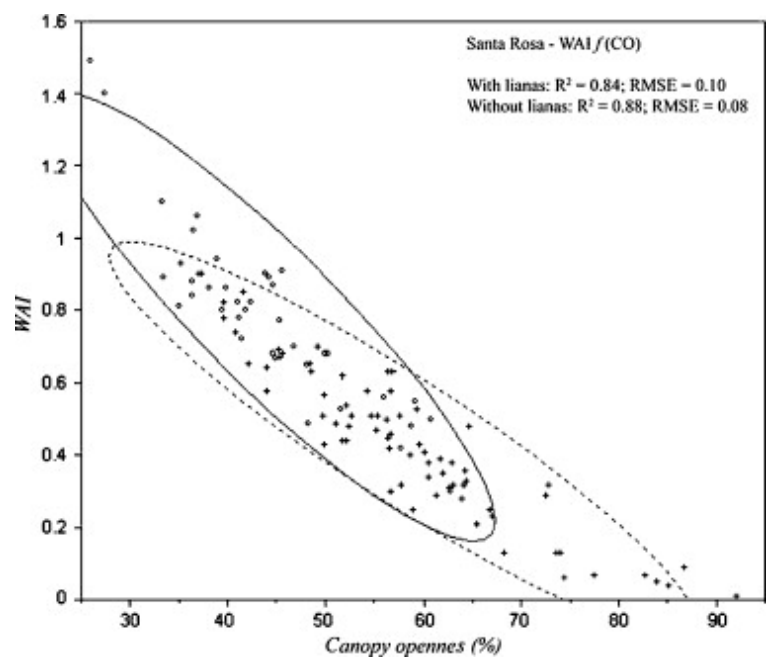

Fig. 6. Relationship between canopy openness (\%) and WAI for Santa Rosa, Costa Rica (b). Open circles and solid line represent data points with lianas, + and dotted line represent data points without lianas. Ellipses represent 95\%. Inset: Mean and one standard deviation for canopy openness (\%) and WAI.

For Palo Verde, when all data are considered (Figs. $\underline{3} \mathrm{c}, \underline{4} \mathrm{c}$ and $\underline{7})$, WAl is greater $\left(\chi^{2}=6.33, P=0.012\right)$ and canopy openness is lower $\left(\chi^{2}=6.21, P=0.013\right)$ for sites with lianas. At the succession stage level, canopy openness is also lower for sites with lianas in the intermediate stage $(Z=-2.01, P=0.04)$ while there is no difference in WAI $(P>0.05)$, nor in either canopy characteristic in the late stage $(P>0.05)$. No lianas were present in the early succession stage.

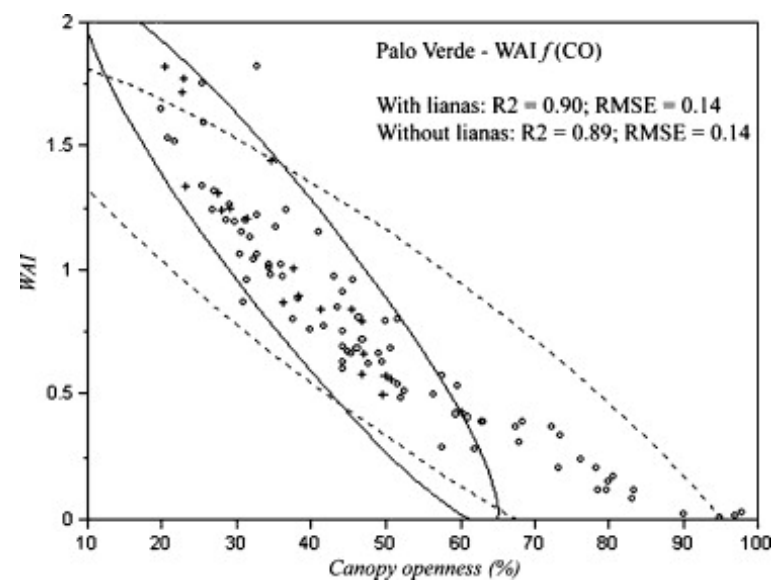

Fig. 7. Relationship between canopy openness (\%) and WAI for Palo Verde, Costa Rica (b). Open circles and solid line represent data points with lianas, + and dotted line represent data points without lianas. Ellipses represent 95\%. Inset: Mean and one standard deviation for canopy openness (\%) and WAI.

In Mata Seca, differences are observed in WAI and canopy openness between sites with and without lianas when all data are considered (CO: $\chi^{2}=41.45, P<0.001$; WAl: $\left.\chi^{2}=45.87, P<0.001\right)$ (Figs. $\underline{3} \mathrm{~d}, \underline{4} \mathrm{~d}$ and $\underline{8}$ ). Differences are also observed at the succession stage level: intermediate (CO: $Z=5.29, P<0.001$; WAI: $Z=5.54, P<0.001$ ) and late succession stages (CO: $Z=3.28, P=0.001 ;$ WAI: $Z=-3.26, P=0.01$ ). No lianas were observed in the early succession stage. 


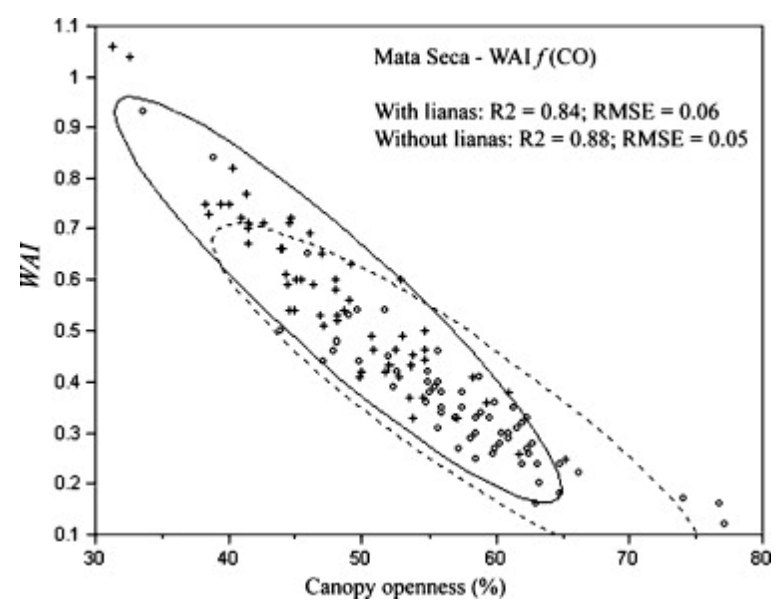

Fig. 8. Relationship between canopy openness (\%) and WAI for Mata Seca, Brazil (b). Open circles and solid line represent data points with lianas, + and dotted line represent data points without lianas. Ellipses represent $95 \%$. Inset: Mean and one standard deviation for canopy openness (\%) and WAI.

\section{Discussion}

Tropical dry forests are ideal study sites for examining the contribution of lianas to wood area index and provide a unique opportunity to gain important insights on how WAI changes as function of successional stage in tropical forests because canopy deciduousness and the high density of lianas (Schnitzer, 2005). As forest disturbance and land abandonment result in more landscapes dominated by secondary, liana-dense dry forests, a better understanding of how changes in WAI affect forest structure is necessary to quantify diverse ecological processes (e.g., regeneration and ecosystem composition), as well as a tool to better characterize parameters needed by terrestrial biosphere models applied to quantify carbon sequestration under different climate change scenarios.

Wood area index represents an important component of accurate estimations of LAI in tropical environments. Our study has documented that, in general, lianas increased WAI with succession in tropical dry forest sites and that canopy openness can be used as a good indictor of their presence for tropical dry forests environments. Fig. 4, Fig. 5, Fig. 6, Fig. 7 indicate that, for the majority of sites studied, lianas are present in sites with a canopy openness of $75 \%$ or higher, which are mostly early and intermediate successional stages. This represents an interesting finding which needs to be validated in other sites and ecosystems.

We hypothesize that lianas are more dominant in the intermediate succession stage as a result of the smaller stature of the canopy and that the species composition observed in this stage is a mix of the fast growing pioneers, dominant canopy trees and shade tolerant trees (Kalácska et al., 2004), creating therefore, an excellent environment for liana growth and development due to the amount of large canopy gaps not present in the Late stage. The majority of the sites considered "intermediate" based on their structure have also been either completely or nearly completely cleared in the past for other land uses or have been extensively disturbed by events such as anthropogenic fires (Kalácska et al., 2004, Kalácska et al., 2005b), in addition none of the sites are used for human activities such as the extraction of liana or tree wood for fuel or charcoal production.

The canopy of all the intermediate succession stage examined in this study is patchy in comparison to the late stage, which tends to have fewer lianas across all sites in the Americas. Lower liana abundance in late sites may result from low light availability that may constrain liana establishment and growth as the canopy closes due to tree growth (Dewalt et al., 2000). The canopy in the late stage is more homogeneous with fewer canopy gaps; lianas preferentially inhabit canopy gaps and disturbed areas (드nitzer and Bongers, 2002). In the later 
succession stages however, there are taller dominant canopy trees in the upper stratum and more shade tolerant species in a second stratum below (Kalácska et al., 2004), which may increase energy costs for liana growth as tree height increases (Baars et al., 1998). In addition, the late stage; while having been disturbed by activities such as selective logging, cattle or anthropogenic fires, it had not been completely cleared (Kalácska et al., 2004, Kalácska et al., 2005b). The one exception is the upper ridge-top forest in Chamela-Cuixmala (undisturbed forest) which has a higher abundance of lianas when compared with all other sites. The canopy of this forest however is only $9 \pm 2.2 \mathrm{~m}$ tall; shorter than trees in the intermediate stages at other sites in the Americas (Table 1). The study area in Chamela-Cuixmala is also the driest. We believe that both factors (tree height and climate) contribute to this unique characteristic of the late stage (upper ridge-top) in ChamelaCuixmala, although it follows observations presented by Schnitzer (2005) which indicates that across the tropics drier sites will have a higher density of lianas.

Our findings using WAI and CO as proxies, also confirm the assertions of Dewalt et al. (2000), who suggested that liana presence will be more dominant in earlier successional stages than in old growth as a result of greater canopy openness (see above). This result is supported by the finding that lianas are not present in plots with a canopy openness higher than $60-75 \%$, which is typical of early successional dry forests and many later secondary dry forests as well (ig. 6, Fig. 7, Fig. 8).

Our results suggest general ecological trends in terms of how WAI changes as a function of successional stage (Table 1). Overall, the earliest stage of regeneration is not greatly affected by lianas and the majority of WAI is from trees. In the intermediate stage however, lianas are an important element, contributing to a canopy that is more closed than would be the case if lianas were not present. In fact, WAI in liana-dominated plots of the intermediate stage can be as high as 1.82 while areas without lianas have more moderate values (i.e., below 1.3).

Finally in a broader context, our results present new and important information that can be used to better calibrate terrestrial ecosystems models that depend on LAI as an input parameter (Abuelgasim et al., 2006). Current LAI datasets produced by NASA's Moderate Resolution Imaging Spectroradiometer (MODIS Version's 4 and 5) that are widely used in the literature for model validation, lack corrections for WAI (Knyazikhin et al., 1998). Since worldwide WAl information is still limited, the information and ranges of variability provided in this study open the door for the possibility of further corrections on LAl estimations, which, in turn, will enhance the accuracy of terrestrial ecosystem models of climate change.

\section{Acknowledgements}

This work was carried out with the aid of a grant from the Inter-American Institute for Global Change Research (IAI) CRN II - 021, which is supported by the US National Science Foundation (Grant GEO-0452325). We are also grateful for the financial support provided by Fundação de Amparo à Pesquisa de Minas Gerais (FAPEMIG CRA 2288/07), as well as Mexico's SEMARNAT-CONACYT under the CIEco-MABOTRO project. We also thank Roger Blanco and Maria Marta Chavarría from the Santa Rosa National Park, Dr. Eugenio Gonzalez and Mauricio Castillo from the Palo Verde National Park for their logistical support as well as Ulises Chavarría (Costa Rica), Roberto Espinoza (Costa Rica), Alfredo Pérez (Mexico), Mauricio Quesada (Mexico) and Gumersindo Sanchez (Mexico). Finally, we would like to thank all the field assistants from the University of Alberta, the Instituto Tecnologico de Costa Rica, the Centro de Investigaciones en Ecosistemas (CIECO), Universidad Nacional Autonoma de Mexico, and Universidade Estadual de Montes Claros - MG, Brazil, for their help in data collection. 


\section{References}

Abuelgasim et al., 2006 A.A. Abuelgasim, R.A. Fernandes, S.G. LeBlanc Evaluation of national and global LAI products derived from optical remote sensing instruments over Canada. IEEE Transactions on Geoscience and Remote Sensing, 44 (2006), pp. 1872-1884

Arroyo-Mora et al., 2005 J.P. Arroyo-Mora, G.A. Sanchez-Azofeifa, M.E.R.Kalácska, B. Rivard, J.C. CalvoAlvarado, D.H. Janzen. Secondary forest detection in a neotropical dry forest landscape using Landsat 7 ETM+ and IKONOS imagery. Biotropica, 37 (2005), pp. 497-507

Baars et al., 1998 R. Baars, D. Kelly, S.D. Sparrow. Liana distribution within native forest remnants in two regions of the South Island, New Zealand. New Zealand Journal of Ecology, 22 (1998), pp. 71-85

Balvanera et al., 2002 P. Balvanera, E. Lott, G. Segura, C. Siebe, A. Islas. Patterns of beta-diversity in a Mexican tropical dry forest. Journal of Vegetation Science, 13 (2002), pp. 145-158

Bonan et al., 2002 Bonan, G.B., Levis, S., Kergoat, L., Oleson, K.W., 2002. Landscapes as patches of plant functional types: an integrating concept for climate and ecosystem models. Global Biogeochemical Cycles 16 (2), Art. No. 1021 May-June.

Chen et al., 1997 J.M. Chen, P.M. Rich, S.T. Gower, J.M. Norman, S.Plummer. Leaf area index of boreal forests: theory, techniques and measurements. Journal of Geophysical Research, 102 (1997), pp. 24429-24443

Clark et al., 2008 D.B. Clark, P.C. Olivas, S.F. Oberbauer, D.A. Clark, M.G.Ryan. First direct landscapescale measurement of tropical rain forest Leaf Area Index, a key driver of global primary productivity. Ecology Letters, 11 (2) (2008), pp. 163-172

Dewalt et al., 2000 S.J. Dewalt, S.A. Schnitzer, J.S. Denslow. Density and diversity of lianas along a chronosequence in a central Panamanian lowland forest. Journal of Tropical Ecology, 16 (2000), pp. 1-19

Duarte et al., 2002 L.S. Duarte, L.R. Dillenburg, L.M.G. Rosa. Assessing the role of light availability in the regeneration of Araucaria angustifolia (Araucariaceae). Australian Journal of Botany, 50 (2002), pp. 741-751

Ferment et al., 2001 A. Ferment, N. Picard, S. Gourlet-Fleury, C. Baraloto. A comparison of five indirect methods for characterizing the light environment in a tropical forest. Annals of Forest Science, 58 (2001), pp. 877-891

Fournier et al., 2003 R.A. Fournier, D. Mailly, J.-M. Walter, K. Soudani. Indirect measurements of forest canopy structure from in-situ optical sensors. M. Wulder, S. Franklin (Eds.), Methods for Remote Sensing of Forests: Concepts and Case Studies, Kluwer Academic Press, Dordrecht (2003), pp. 77-114

Frankie et al., 1974 G.W. Frankie, H.G. Baker, P.A. Opler. Comparative phenological studies of trees in tropical wet and dry forests in lowlands of Costa Rica. Journal of Ecology, 62 (1974), pp. 881919

Hegarty and Caballé, 1992 E.E. Hegarty, G. Caballé. Distribution and abundance of vines in forest communities. F.E. Putz, H.A. Mooney (Eds.), The Biology of Vines, Cambridge University Press, Cambridge, United Kingdom (1992), pp. 313-335

Hoffmann et al., 2005

W.A. Hoffmann, E.R. Silva, G.C. Machado, S.J. Bucci, F.G. Scholz, G. Goldstein, F.C. Meinzer. 
Seasonal leaf dynamics across a tree density gradient in a Brazilian savanna.

Oecologia, 145 (2005), pp. 307-316

Instituto Estadual de Florestas, 2000 Instituto Estadual de Florestas, 2000. Parecer técnico para a

criação do Parque Estadual da Mata Seca. Instituto Estadual de Florestas, Belo Horizonte-MG, Brazil.

Janzen, 1988a D.H. Janzen. Ecological characterization of a Costa Rican dry forest caterpillar fauna.

Biotropica, 20 (1988), pp. 120-135

Janzen, 1988b D.H. Janzen. Management of habitat fragments in a tropical dry forest - growth.

Annals of the Missouri Botanical Garden, 75 (1988), pp. 105-116

Janzen, 1988c D.H. Janzen. Tropical ecological and biocultural restoration. Science, 239 (1988),

pp. 243-244

Janzen, 2000 D.H. Janzen. Costa Rica's Area de Conservacion Guanacaste: a long march to survival through non-damaging biodevelopment. Biodiveristy, 1 (2000), pp. 7-20

Kalácska et al., 2004 M. Kalácska, G.A. Sanchez-Azofeifa, J.C. Calvo-

Alvarado, M. Quesada, B. Rivard, D.H. Janzen. Species composition, similarity and diversity in three successional stages of a seasonally dry tropical forest. Forest Ecology and

Management, 200 (2004), pp. 227-247

Kalácska et al., 2005a M. Kalácska, J.C. Calvo-Alvarado, G.A. Sanchez-Azofeifa. Calibration and

assessment of seasonal changes in leaf area index of a tropical dry forest in different stages of succession. Tree Physiology, 25 (2005), pp. 733-744

Kalácska et al., 2005b M. Kalácska, G.A. Sanchez-Azofeifa, J.C. Calvo-Alvarado, B. Rivard, M. Quesada.

Effects of season and successional stage on leaf area index and spectral vegetation indices in three mesoamerican tropical dry forests. Biotropica, 37 (2005), pp. 486-496

Kalácska et al., 2007 M. Kalácska, S. Bohlman, G.A. Sanchez-Azofeifa, K.L.Castro-Esau, T. Caelli.

Hyperspectra discrimination of tropical dry forest lianas and trees: comparative data

reduction approaches at the leaf and canopy levels. Remote Sensing of

Environment, 109 (4) (2007), pp. 406-415

Knyazikhin et al., 1998 Y. Knyazikhin, J.V. Martonchik, R.B. Myneni, D.J.Diner, S.W. Running. Synergistic

algorithm for estimating vegetation canopy leaf area index and fraction of absorbed

photosynthetically active radiation from MODIS and MISR data. Journal of Geophysical

Research, 103 (1998), pp. 32257-32276

Kucharik et al., 1998 C.J. Kucharik, J.M. Norman, S.T. Gower. Measurements of branch area and adjusting leaf area index indirect measurements. Agricultural and Forest

Meteorology, 91 (1998), pp. 69-88

Laurance et al., 2001 W.F. Laurance, D. Pérez-

Salicrup, P. Delamonica, P.M.Fearnside, S. D’Angelo, A. Jerozolinski, L. Pohl, T.E. Lovejoy. Rain forest fragmentation and the structure of Amazonian liana communities. Ecology, 82 (2001),

pp. 105-116

Leblanc and Chen, 2001 S.G. Leblanc, J.M. Chen. A practical scheme for correcting multiple scattering effects on optical LAI measurements. Agricultural and Forest Meteorology, 110 (2001), pp. 125-139 
Liao et al., 2006 J.H. Liao, H.H. Wang, C.C. Tsai, Z.Y. Hseu. Litter production, decomposition and nutrient return of uplifted coral reef tropical forest. Forest Ecology and Management, 235 (2006), pp. 174-185

Lott, 1985 Lott, E., 1985. Listado floristicos de Mexico III. La Estacion de Biologia Chamela, Jalisco. Instituto de Biologia, Universidad Autonoma de Mexico, Mexico.

Lott et al., 1987 E.J. Lott, S.H. Bullock, J.A. Solis-Magallanes. Floristic diversity and structure of upland and arroyo forests of coastal Jalisco. Biotropica, 19 (1987), pp. 228-235

Lucas et al., 2002 R.M. Lucas, M. Honzak, I.D. Amaral, P.J. Curran, G.M.Foody. Forest regeneration on abandoned clearances in central Amazonia. International Journal of Remote Sensing, 23 (2002), pp. 965-988

Maass et al., 1995 J.M. Maass, J.M. Vose, W.T. Swank, A. Martinez-Yrizar. Seasonal changes of leaf area index (LAI) in a tropical deciduous forest in West Mexico. Forest Ecology and Management, 74 (1995), pp. 171-180

Maass and Martinez-Yrizar, 2001 Maass, M., Martinez-Yrizar, A., 2001. Tropical forest: Chamela, 19821995. Data set. Oak Ridge National Laboratory Distributed Archive, Oak Ridge Tennessee.

Mohan et al., 2006

J.E. Mohan, L.H. Ziska, W.H. Schlesinger, R.B. Thomas, R.C. Sicher, K. George, J.S. Clark. Biomass and toxicity responses of poison ivy (Toxicodendron radicans) to elevated atmospheric $\mathrm{CO}_{2}$. Proceeding of the National Academy of Sciences of the United States of America, 103 (24) (2006), pp. 9086-9089

Montgomery and Chazdon, 2001 R.A. Montgomery, R.L. Chazdon. Forest structure, canopy

architecture, and light transmittance in tropical wet forests. Ecology, 82 (2001), pp. 2707-2718

Morisette et al., 2006

J.T. Morisette, F. Baret, J.L. Privette, R.B. Myneni, J.E.Nickeson, S. Garrigues, N.V. Shabanov, M. Weiss, R.A. Fernandes, S.G.Leblanc, M. Kalácska, G.A. SanchezAzofeifa, M. Chubey, B. Rivard, P.Stenberg, M. Rautiainen, P. Voipio, T. Manninen, A.N. Pilant, T. E.Lewis, J.S. liames, R. Colombo, M. Meroni, L. Busetto, W.B. Cohen, D.P. Turner, E.D. Warner, G .W. Petersen, G. Seufert, R. Cook. Validation of global moderate-resolution LAI products: a framework proposed within the CEOS Land Product Validation subgroup. IEEE Transactions on Geoscience and Remote Sensing, 44 (2006), pp. 1804-1817

Oberbauer et al., 1993 S.F. Oberbauer, D.B. Clark, D.A. Clark, P.M. Rich, G.Vega. Light environment, gas exchange, and annual growth of saplings of 3 species of rainforest trees in Costa Rica. Journal of Tropical Ecology, 9 (1993), pp. 511-523

Palomaki et al., 2006 M.B. Palomaki, R.L. Chazdon, J.P. Arroyo, S.G. Letcher. Juvenile tree growth in relation to light availability in second-growth tropical rain forests. Journal of Tropical Ecology, 22 (2006), pp. 223-226

Pérez-Salicrup, 2001 D.R. Pérez-Salicrup. Effect of liana cutting on tree regeneration in a liana forest in Amazonian Bolivia. Ecology, 82 (2001), pp. 389-396

Pérez-Salicrup et al., 2001 D.R. Pérez-Salicrup, V.L. Sork, F.E. Putz. Lianas and trees in a liana forest of Amazonian Bolivia. Biotropica, 33 (2001), pp. 34-47

Pérez-Salicrup and de Meijere, 2005 D.R. Pérez-Salicrup, W. de Meijere. Number of lianas per tree and number of trees climbed by lianas at Los Tuxtlas, Mexico. Biotropica, 37 (2005), pp. 153-156 


\section{Phillips et al., 2002}

O.L. Phillips, R.V. Martinez, L. Arroyo, T.R. Baker, T.Killeen, S.L. Lewis, Y. Malhi, A.M. Mendoza, D . Neill, P.N. Vargas, M.Alexiades, C. Ceron, A. Di

Fiore, T. Erwin, A. Jardim, W. Palacios, M.Saldias, B. Vinceti. Increasing dominance of large

lianas in Amazonian forests. Nature, 418 (2002), pp. 770-774

Putz, 1983 F.E. Putz. Liana biomass and leaf area of a Tierra Firme Forest in the Rio-Negro Basin,

Venezuela. Biotropica, 15 (1983), pp. 185-189

Rzedowski, 1978 Rzedowski, J., 1978. Vegetacion de Mexico. Editorial Limusa, Mexico.

Saldarriaga and Luxmoore, 1991 J.G. Saldarriaga, R.J. Luxmoore. Solar energy conversion efficiencies

during succession of a tropical rain forest in Amazonia. Journal of Tropical Ecology, 7 (1991),

pp. 233-242

Schnitzer, 2005 S.A. Schnitzer. A mechanistic explanation for global patterns of liana abundance and distribution. American Naturalist, 166 (2005), pp. 262-276

Schnitzer and Bongers, 2002 S.A. Schnitzer, F. Bongers. The ecology of lianas and their role in forests.

Trends in Ecology \& Evolution, 17 (2002), pp. 223-230

SFU-IES, 1999 SFU-IES, 1999. Gap Light Analyzer v.2.0.

Stern et al., 2002 M. Stern, M. Quesada, K.E. Stoner. Changes in composition and structure of a tropical dry forest following intermittent cattle grazing. Revista de Biologia Tropical, 50 (2002), pp. 1021-1034

Szott et al., 1994 L.T. Szott, C.A. Palm, C.B. Davey. Biomass and litter accumulation under managed and natural tropical fallows. Forest Ecology and Management, 67 (1994), pp. 177-190

Welles, 1990 J.M. Welles. Some indirect methods of estimating canopy structure. Remote Sensing Reviews, 5 (1990), pp. 31-43

Welles and Cohen, 1996 J.M. Welles, S. Cohen. Canopy structure measurement by gap fraction analysis using commercial instrumentation. Journal of Experimental Botany, 47 (1996), pp. 1335-1342

Wright et al., 2004 S.J. Wright, O. Calderon, A. Hernandez, S. Paton. Are lianas increasing in importance in tropical forests? A 17-Year record from Panama. Ecology, 85 (2) (2004), pp. $484-$ 489 